\title{
THE REACTION OF ASSET PRICES TO MACROECONOMIC ANNOUNCEMENTS IN NEW EU MARKETS: EVIDENCE FROM INTRADAY DATA
}

\author{
Jan Hanousek \\ Evžen Kočenda \\ Ali. M. Kutan
}
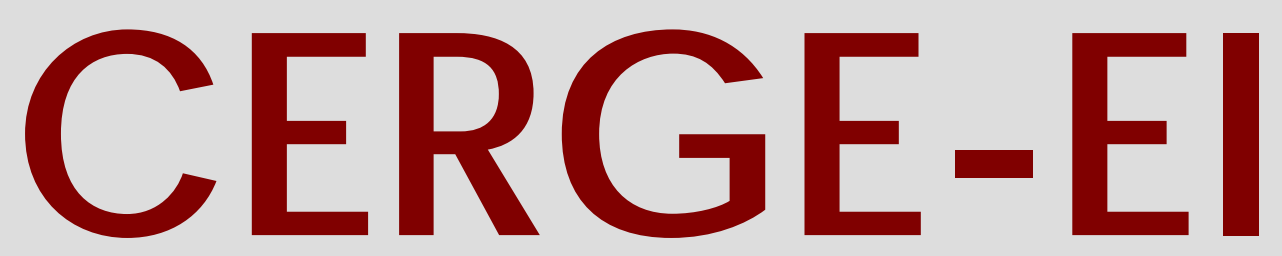

Charles University CenterforEconomic Research and Graduate Education Academy of Sciences of the Czech Republic Ec onomic s Institute 


\section{Working Paper Series 349 (ISSN 1211-3298)}

\section{The Reaction of Asset Prices to Macroeconomic Announcements in New EU Markets: Evidence from Intraday Data}

Jan Hanousek Evžen Kočenda Ali M. Kutan

CERGE-EI

Prague, March 2008 
ISBN 978-80-7343-149-5 (Univerzita Karlova. Centrum pro ekonomický výzkum a doktorské studium)

ISBN 978-80-7344-138-8 (Národohospodářský ústav AV ČR, v.v.i.) 


\title{
The Reaction of Asset Prices to Macroeconomic Announcements in New EU Markets: Evidence from Intraday Data
}

\author{
Jan Hanousek*, Evžen Kočenda**, Ali M. Kutan***
}

\begin{abstract}
We estimate the impact of macroeconomic news on composite stock returns in three emerging European Union financial markets (the Budapest BUX, Prague PX-50, and Warsaw WIG-20), using intraday data and macroeconomic announcements. Our contribution is twofold. We employ a larger set of macroeconomic data releases than used in previous studies and also use intraday data, an excess impact approach, and foreign news to provide more reliable inferences. Composite stock returns are computed based on five-minute intervals (ticks) and macroeconomic news are measured based on the deviations of the actual announcement values from their expectations. Overall, we find that all three new EU stock markets are subject to significant spillovers directly via the composite index returns from the EU, the U.S. and neighboring markets; Budapest exhibits the strongest spillover effect, followed by Warsaw and Prague. The Czech and Hungarian markets are also subject to spillovers indirectly through the transmission of macroeconomic news. The impact of EU-wide announcements is evidenced more in the case of Hungary, while the Czech market is more impacted by U.S. news. The Polish market is marginally affected by EU news. In addition, after decomposing pooled announcements, we show that the impact of multiple announcements is stronger than that of single news. Our results suggest that the impact of foreign macroeconomic announcements goes beyond the impact of the foreign stock markets on Central and Eastern European indices. We also discuss the implications of the findings for financial stability in the three emerging European markets.
\end{abstract}

Keywords: stock markets, intraday data, macroeconomic announcements, European Union, volatility, excess impact of news

JEL Classification: C52, F36, G15, P59

\footnotetext{
* CERGE-EI, Charles University and the Academy of Sciences, Prague, Czech Republic; The William Davidson Institute, Michigan; and CEPR, London.

** CERGE-EI, Charles University and the Academy of Sciences, Prague, Czech Republic; The William Davidson Institute, Michigan; CEPR, London; and Euro Area Business Cycle Network.

*** Southern Illinois University Edwardsville; The Center for European Integration Studies, Bonn; The Emerging Markets Group, London; and The William Davidson Institute, Michigan.
}

We would like to thank Lieven Baele, Jan Bena, Jarko Fidrmuc, Petr Koblic, Petr Sklenář, Vilém Semerák and Petr Zemčík for helpful comments. GAČR grant (402/08/1376) support is gratefully acknowledged. The usual disclaimer applies. 


\begin{abstract}
Abstrakt
Analyzujeme dopad makroekonomických zpráv na výnosy akciových indexů na třech finančních trzích nových členských zemí EU (Budapešt'-BUX, Praha-PX50, Varšava-WIG) za použití vysokofrekvenčních pětiminutových dat. Ve srovnání s jinými pracemi používáme rozsáhlejší soubor makroekonomických zpráv, pracujeme s vysokofrekvenčními daty, a metodologicky zohledňujeme rozsah zpráv vůči očekáváním trhu. Výnosy akciových indexů jsou počítány na základě pětiminutových intervalů a makroekonomické zprávy jako odchylky zpráv od jejich očekávání na trhu. Celkově jsou tři zkoumané trhy pod př́mým vlivem trhů EU a USA, který se přelévá prostř̌ednictvím tržních indexů. Nejsilnější přeliv zaznamenává Budapešt', poté Varšava a Praha. Český a mad'arský trh je také zasažen nepřímými přelivy prostřednictvím makroekonomických zpráv. Mad’arský trh je více citlivý na evropské zprávy, na českém trhu mají větší dopad zprávy americké. Polský trh je pouze marginálně pod vlivem evropských zpráv. Rozsah zpráv je rovněž důležitý: dopad zpráv, které přicházejí ve skupinách je silnější než u jednotlivých zpráv. Naše výsledky ukazují, že dopad zahraničních makroekonomických zpráv jde dál nad rámec přímého vlivu zahraničních trhů na tržní indexy středoevropských zemí. Naše výsledky vztahujeme také k finanční stabilitě na těchto trzích.
\end{abstract}




\section{Introduction, Motivation and Related Literature}

In this paper we analyze the impact of macroeconomic announcements on stock market returns using intraday data from the three most liquid emerging European Union markets: the Czech Republic, Hungary, and Poland. Our paper contributes to the related literature in several ways. First, to our knowledge, there are no studies investigating the direct impact of macroeconomic news on emerging EU stock markets using intraday data. Previous studies focus on advanced stock markets, especially on the German, U.S., and UK stock markets. Overall, a limited number of studies investigate stock markets in Central and Eastern Europe. ${ }^{1}$ The only study that is closely related to ours is a recent work by Nikkinen, Omran, Sahlström and Äijö (2006) who analyze the behavior of volatilities around ten important scheduled U.S. macroeconomic announcements ${ }^{2}$ on stock markets in several world regions, including the Czech Republic, Poland, Hungary, Slovakia, and Russia. Using cross-sectional monthly data, they find that these transition markets as a group are not affected by U.S. announcements. The monthly data they use, however, may not capture the true spillovers effects of foreign news announcements on local markets. We provide time series evidence and use intraday data to provide more precise findings.

Second, recent research accentuates the significance of using intraday data to reveal the importance of macroeconomic announcements on stock market activity. High-frequency studies include Anderson, Bollerslev and Cai (2000), Nikkinen and Sahlström (2004), Jones, Lin and Masih (2005), Erenburg, Kurov and Lasser (2005), and Rigobon and Sack (2006). In this paper, as an extension of this scant but growing literature, we use stock price data based on 5-minute intervals to provide more robust estimates of public information on stock returns. Although these studies focus on developed markets' stock prices, we use data from European emerging markets.

Third, the majority of studies focus only on a few macroeconomic announcements. In particular, most of them analyze only one event, namely the impact of monetary policy news

\footnotetext{
${ }^{1}$ Zalewska-Mitura and Hall (1999) and Chun (2000) analyze efficiency issues in the Budapest stock market. Tse, Wu and Young (2003) investigate the transmission of shocks from the U.S. stock market to the Warsaw stock exchange. Mateus (2004) examines the sources of risk and the degree of predictability of returns in the stock markets of 13 EU accession countries. Korczak and Bohl (2005) investigate the changes in stock prices and trading volume around depositary receipts issuance on a sample of Czech, Hungarian, Polish, Russian, Slovak and Slovenian stocks. Serwa and Bohl (2005) investigate the contagion effects of several financial shocks in the stock markets of Central and Eastern Europe. The remaining studies discuss the development of stock markets in Central and Eastern Europe, including Fink, Haiss, Orlowski and Salvatore (1998), Hermes and Lensink (2000), Rockinger and Urga (2000), and Scholtens (2000).

${ }^{2}$ The announcements considered are consumer confidence, consumer price index, employment cost index, employment situation, gross domestic product, import and export price indices, manufacturing and nonmanufacturing, producer price index, and retail sales.
} 
on stock returns. ${ }^{3}$ However, if there are other major announcements in the same time frame, then focusing only on monetary policy or only a few announcements may bias the estimated coefficients and hence may explain the poor performance of macroeconomic announcements in explaining asset returns. To our knowledge, Flannery and Protopapadakis (2002) have so far employed the most comprehensive set of local announcements, which includes 17 U.S. macroeconomic data releases. ${ }^{4}$ However, we believe that financial markets react to all types of macroeconomic news; hence we use a larger set of macroeconomic releases than employed in previous studies. Our focus is on the overall impact of macroeconomic news, rather than their individual contributions. ${ }^{5}$

Fourth, previous studies mainly focus on local macroeconomic announcements. Investors may also react to foreign macroeconomic announcements if there are significant trade and financial linkages or institutional arrangements between countries. To our knowledge, there are only a few studies that investigate the impact of both local and foreign announcements on stock market returns. Nikkinen and Sahlström (2004) examine the relative importance of domestic and U.S. macroeconomic news in two European stock markets, Germany and Finland. They find that U.S. news moves both European markets while domestic news seems to be insignificant. Albuquerque and Vega (2006) investigate the impact of domestic and foreign (U.S.) news about economic fundamentals on the correlation of stock returns between the U.S. and Portugal. They find that cross-country correlations decline when domestic (Portuguese) news is released but unchanged when foreign (U.S.) news is released. Also, U.S. public information arrival influences Portuguese stock returns; however, this effect is much smaller when U.S. stock market returns are included in estimations. The latter finding suggests that only the macroeconomic news that impacts the U.S. stock market has an impact on the Portuguese stock market.

The limited evidence indicates that foreign news arrival may have important implications for stock valuation. We extend these studies to the case of three emerging EU markets. We use regional and foreign macro news, apart from local news. Local news is much less frequent than regional and foreign news, but more importantly the majority of local news

\footnotetext{
${ }^{3}$ These studies include Jensen and Johnson (1995), Jensen, Mercer, and Johnson (1996), Patelis (1997), Thorbecke (1997), Siklos and Anusiewicz (1998), Bomfim (2001), Ehrmann and Fratzscher (2004, 2006), Gurkaynak, Sack and Swanson (2004), Mann, Atra and Dowen (2004), Rigobon and Sack (2006), Bredin, Hyde, and O'Reilly (2005), He (2006), and Wongswan (2006).

${ }^{4}$ They include balance of trade, consumer credit, construction, CPI, employment (non-farm) and unemployment, home sales, home starts, industrial production, leading indicators, M1, M2, personal consumption and personal income, producer price index, real GNP, and sales.

${ }^{5}$ Whether the individual impacts of different announcements are the same or different is an interesting empirical question, and we leave this issue to further study.
} 
is released before trading begins; hence it cannot affect stocks during trading hours. In particular, we use news from other EU markets, mainly Germany, and the U.S. This set of news is interesting because Germany, apart from being an important trading partner, is part of the European monetary union. News from Germany may affect emerging EU markets substantially since the emerging markets aspire to join the monetary union, even if they have not yet determined when entry will occur (see Fidrmuc and Korhonen, 2003 and 2006). In addition, investors may also utilize information from neighboring markets and world markets (proxied by the U.S.). Overall, we provide a richer set of foreign news than is utilized in the literature, capturing institutional arrangements, trade and financial links through neighboring countries, and global market linkages.

Fifth, previous studies tend to investigate the impact of macro news only on conditional returns, assuming that stock returns do not exhibit time-varying volatility. ${ }^{6}$ In this study, we model both conditional returns and the conditional variance of returns simultaneously in a time-varying (SUR-GARCH) framework to better capture the impact of macroeconomic announcements of stock returns and stock market volatility in the three emerging EU markets.

Finally, our paper is related to the literature on cross-market correlations between stock markets (e.g., Albuquerque and Vega, 2006). Our findings can shed light on the question of whether the source of any observed correlations among stock markets is due to economic fundamentals contained in public announcements rather than "contagion". For example, if U.S. macroeconomic announcements have explanatory power in the variations of stock prices in emerging EU markets, this would suggest that economic fundamentals are responsible for the co-movements between the U.S. and the emerging EU markets. The few studies summarized above on Central and Eastern European stock markets do not provide comprehensive evidence regarding cross market linkages between these markets and the rest of the world.

From a broader perspective, the current study should be of interest to investors and policymakers as the markets studied are relatively new and have been under the influence of dramatic reforms and privatization efforts since the early 1990s. In addition, they have been subject to global shocks due to opening up their economy to world trade and foreign direct investment. Furthermore, their recent efforts to enter the Exchange Rate Mechanism II of the

\footnotetext{
${ }^{6}$ These studies include Jensen et al. (1996), Patelis (1997), Siklos and Anusiewicz (1998), Flannery and Protopapadakis (2002), Gurkaynak et al. (2004), Nikkinen and Sahlström (2004), Bredin et al. (2005), Albuquerque and Vega (2006), He (2006) and Ramchander et. al (2006). On the other hand, Kim and In (2002), Bomfim (2001), Kim et al. (2004), and Jones et al. (2005) utilize time-varying (GARCH) models.
} 
European Monetary Union and hence the euro zone mean that they will be subject to further external shocks. In this process, it would be interesting to observe how these markets respond to the arrival of information from the EU and the U.S. Because such news from these foreign countries reflects underlying future economic shocks to local economies, our findings may provide a better understanding of investor behavior in these emerging markets in such an environment and allow us to observe whether they respond differently to macroeconomic news in emerging markets compared to those in advanced stock markets. The results are also useful for developing strategic investment decisions, as these markets are considered to be relatively larger, more open, and more liquid than others in the Central and Eastern European region. Hence, foreign investors are more likely to utilize these markets than others in the region for their portfolio decisions.

\section{Data and Methodology}

We analyze the impact of news on stock returns in new EU stock markets concentrating on the stock exchanges in Budapest, Prague, and Warsaw in particular. ${ }^{7}$ These markets are the largest European emerging markets in terms of market capitalization as well as the extent of liquidity (Égert and Kočenda, 2007).

We analyze the impact of announcements by employing an augmented version of the generalized autoregressive conditional heteroskedasticity (GARCH) model attributed to Bollerslev (1986). Since the reasoning behind the augmentation of the model requires a knowledge of our approach with respect to announcements, we deviate from the standard sequencing and introduce our data prior to describing the model. ${ }^{8}$

\subsection{Data Set: Stocks and News}

We constructed our dataset from intraday data recorded by Bloomberg for the stock markets of three emerging EU markets. Stock exchange index quotes are available in five-minute intervals (ticks) for the stock markets in Budapest (BUX), Prague (PX-50), and Warsaw (WIG-20). The time period of our data starts on 2 June 2003 at 9:00 and ends on 29 December 2006 at 16:00 Central European Daylight Time (CEDT), which gives a total of 876 trading days after accounting for weekends and public holidays. A trading day is represented by the

\footnotetext{
${ }^{7}$ Returns are stationary series. Results of stationarity tests not reported.

${ }^{8}$ A theoretical framework linking macro announcements to stock returns is underdeveloped. We refer readers to account of the bond pricing with announcement effects of Piazzesi (2001) and the equities modeling framework with announcements' effect of Mamaysky (2002).
} 
trading window when the new EU markets are simultaneously in a trading session. Descriptive statistics of the stock indices are presented in Table 1.

The composition of the three indices is provided in Table A1 in the Appendix. The Budapest index BUX consists of 14 titles, with four forming the bulk of the index $(92.3 \%)$ : Magyar Telekom, MOL (oil and gas processing), OTP (banking), and Richter (pharmaceutical). The Prague index (PX-50) consists of 11 titles but $80.5 \%$ of it is formed by four titles: CEZ (electricity energy), Erste Bank (banking), Telefonica O2 (telecom), and Komerční banka (banking). The Warsaw index WIG-20 contains 20 titles and five titles form a majority (61.6\%): PKO Bank Polski (banking), Bank PEKAO (banking), PKN Orlen (oil processing), TP SA (telecom), and KGHM (copper and silver mining and metallurgy). The Hungarian index contains only domestic issues while the Czech and Polish indices contain also foreign stocks. In the Polish index, foreign stocks constitute a negligible minority representing some energy companies from the Czech Republic and Hungary. All companies that are included in the three indices are obliged to report under international accounting standards and are, hence, not exposed to foreign economic conditions in a different way in terms of reporting activities. All three indices are composed of stocks representing a variety of economic sectors whose weights vary across the indices. The energy, banking and telecom industries dominate all three indices and specifically the banking industry is represented in similar proportions in the three markets. The index composition is then to a large extent representative of each country's economy without any strong concentration in a specific industry. If there is any bias towards banking, the index composition hints that at least it is consistent across the three countries. In the same spirit all three countries exhibit a similarly consistent trading pattern with respect to the U.S. and the old EU-15. International trade turnover with the U.S. ranges from 1 to $2.5 \%$ and is dwarfed by the turnover with the EU that ranges from 50 to $65 \%$ depending on the country. Therefore, among the three countries there is not one that would have closer economic ties with the EU or the U.S. than the others.

Further, we compiled an extensive data set on the macroeconomic announcements (news) in the above markets as well as announcements in the EU and the U.S. The news in our sample can be divided into five categories. These are announcements on nominal macroeconomic aggregates (consumer price index, labor costs), real economy (GDP, current account, production, sales, trade balance, unemployment, etc.), monetary policy (monetary aggregate and interest rate), fiscal policy (debt, deficit, expenditures), and economic confidence (consumer and industry confidence, business climate, etc.). In terms of the timing of news releases there is a major obstacle. Unfortunately, the vast majority of local news is 
released intentionally before the market opening and thus they are absorbed by the market before trading begins as we document presently. For this reason, we are able to study chiefly the effect of foreign news. Altogether there are 1372 occasions at which announcements originating in the EU or the U.S. are released during the trading window common for all three new EU markets.

The announcements are defined in the following way. There is news $i$ in the form of various macroeconomic releases or announcements that are known ahead of time to materialize on specific dates $t .^{9}$ The extent of such news is not known but expectations on the market form a forecast whose values are factored in. Thus, the impact of such news materializes through their difference from market expectations rather than from the extent of the news itself. Therefore, we define the news in our data set from the excess impact perspective. Since announcements are often reported in different units, news is standardized as the percentage deviation from the market expectation. The excess impact news variable is labeled as $x n_{k t}$ and formally defined as $x n_{k t}=\left(100\left(s n_{k t}-\mathrm{E}_{t-1}\left[s n_{k t}\right]\right) / \mathrm{E}_{t-1}\left[s n_{k t}\right]\right)$, where $s n_{k t}$ stands for the value or extent of the scheduled announcement and $\mathrm{E}_{t-1}\left[s n_{k t}\right]$ is the value expected by the market. For the purpose of our analysis we collected macroeconomic news for which there exists a Bloomberg or Reuters survey including a clearly defined calendar of releases with defined timing of news as well as their expectations. The vector $x n_{k}$ contains all news pooled together but announcements may be released in groups or they are released as single announcements. The effects of multiple news $\left(M x n_{k}\right)$ are difficult to decompose and therefore we group multiple announcements into a specific category for the purpose of estimation. Single news $\left(S x n_{k}\right)$ are for the estimation also grouped in a separate vector. ${ }^{10}$

Table 2 provides information on the distribution of the news in all 876 trading days with respect to their origins. The proportion of days when no news is released is relatively high in the EU (70\%) as the proportion for the U.S. is less than half the EU value (31\%). The proportion of days when only a single news is released is roughly similar for both economies but the number of days with only multiple announcements is three times larger in the U.S. $(18 \%)$ than in the EU (6\%). The proportion of days when both single as well as multiple news are released does not reach a meaningful percentage in the EU but is one fifth of the days in

\footnotetext{
${ }^{9}$ There is also news in the form of an unexpected announcement that can be understood as a truly exogenous shock or surprise. The number of such news that is recorded is negligible and we do not consider them in the present study.

${ }^{10}$ We acknowledge the referee's suggestion to consider multiple versus single news effects. At the estimation stage we do not differentiate among the various types of news. We have run preliminary regressions but learned that the division of the news into categories dilutes their effect as the majority of the obtained estimates were insignificant.
} 
the U.S. Finally, we can see that the proportion of days when there is no announcement is very high for the new EU markets (above 90\% for Prague and Budapest, and above 75\% for Warsaw) as the vast majority of local news is released before the market opens. Only small proportions of days feature single news events during the trading session; this proportion is negligible for Prague and Budapest. Only Warsaw features small proportion of days (10\%) when multiple news are released and a negligible proportion of combined releases.

From a practical perspective, we consider each new announcement within 5 minutes after release and account for its effect for another 10 minutes. Following the excess impact approach described above, we differentiate the positive $(+)$ and negative (-) impact of the announcement in terms of its relation to market expectations. In the majority of cases the announcement has a positive (negative) impact if it is above (below) market expectations. However, there are some announcements where the impact direction is reversed. For example, a higher than expected unemployment rate has a negative impact as its consequence means lower tax collection, increased payments from state, etc. On the other hand, lower than expected inflation has a positive impact. Other variables whose announcement shows a reverse impact direction are, for example, debt, deficit, interest rate, and labor costs. Finally, an announcement has a zero impact if it is in line with the market. ${ }^{11}$ The time difference between the markets is accounted for by setting the CEDT time for all news releases, which eliminates the time difference between the U.S. and continental Europe.

As a complement to the above news distribution we also provide information on the news from the excess impact perspective. The division is based on the number of events when news is released during the trading window. Out of 1372 occasions in which announcements originating in the EU and the U.S. are released, there is $42.06 \%$ positive news in terms of market expectations, $41.62 \%$ negative news, and $16.33 \%$ news that are in line with market expectations. It is evident that the distribution of surprises is almost 50/50 positive/negative as the number of positive news is only marginally higher. A finer distinction of the news categories is provided in Table 3. The total number of EU and U.S. announcements that are in line with expectations is about five times smaller than the total number of announcements that come as a negative or positive surprise. Further, the proportion of the positive and negative news originating in the U.S. is about four times higher than that of EU news, but only twice as large when news with no impact are considered. An even finer distinction can be made when

\footnotetext{
${ }^{11}$ At the estimation stage we consider announcements that are exactly in line with market expectations compared to the wider set of news that deviates from market expectations by $\pm 2 \%$ and thus can be still considered as being in line with the market. Both estimations yield identical results.
} 
classifying news events into single and multiple categories. Both positive and negative surprises from the U.S. are several times more frequent than those coming from the EU. The feature is similar but less pronounced for multiple but reversed for single in-line-with-themarket news. Announcement events during the trading window and originating in the new EU markets are a fraction when compared to the EU and the U.S., and only Poland stands out somewhat.

\subsection{Estimation Methodology}

We employ the augmented generalized autoregressive conditional heteroskedasticity (GARCH) model attributed to Bollerslev (1986) to empirically test for stock market volatility. We augment the mean specification by parameters to account for the effect of macroeconomic news in the form of deviations of scheduled releases from market expectations, and the effects of spillovers from neighboring emerging markets as well as two major developed markets (Germany and the U.S.). In effect our model specification allows for intra-regional spillovers, as well as those from developed markets. ${ }^{12}$ We use a GARCH-in-mean (GARCH-M) specification which includes a conditional variance in the mean equation so that we can analyze the process with the path-dependent rather than the zero-conditional mean. The baseline model is specified in the following form:

$$
\begin{gathered}
\Delta S I_{i, t}^{E}=\sum_{k \in\{E U, U S\}} \sum_{j=1}^{q} \rho_{k} \Delta S I_{k, t-j}^{D}+\sum_{i=1}^{2} \sum_{j=1}^{p} \mu_{i} \Delta S I_{i, t-j}^{E}+ \\
+\sum_{k \in\{E U, U S\}} \sum_{j \in\{+,-, 0\}} \chi_{k j} x n_{k}^{j}+\theta \ln h_{i, t}+\varepsilon_{t} \\
\Delta S I_{i, t}^{E}=\sum_{k \in\{E U, U S\}} \sum_{j=1}^{q} \rho_{k} \Delta S I_{k, t-j}^{D}+\sum_{i=1}^{2} \sum_{j=1}^{p} \mu_{i} \Delta S I_{i, t-j}^{E}+ \\
+\sum_{k \in\{E U, U S\}} \sum_{j \in\{+,-, 0\}} \gamma_{k j} S x n_{k}^{j}+\sum_{k \in\{E U, U S\}} \sum_{j \in\{+,-, 0\}} \delta_{k j} M x n_{k}^{j}+\theta \ln h_{i, t}+\varepsilon_{t} \\
h_{i, t}=\omega+\sum_{m=1}^{r} \alpha_{m} \varepsilon_{t-m}^{2}+\sum_{m=1}^{s} \beta_{m} h_{i, t-m} .
\end{gathered}
$$

The two mean equations are alternative specifications to account for the pooled announcements (1.A) and to distinguish between single and multiple news (1.B). The

\footnotetext{
${ }^{12}$ The specification allows for both types of spillovers as we do not want to exclude the possibility that the impact of macroeconomic announcements could transmit via stock pricing in foreign (developed) markets instead of only a simple direct effect. The effect of these two channels is limited for the U.S. announcements that are released before the U.S. stock exchange opening hours, but can be stronger for the EU market. As there is an overlap of trading hours between the EU markets and the Czech, Hungarian and Polish markets, any EU macroeconomic releases analyzed in this paper are made during EU trading hours.
} 
variables used are coded as follows. Our dependent variable $\Delta S I_{i, t}^{E}$ is return on a specific emerging $(E)$ market stock index $i$ (Budapest, Prague, Warsaw) at time $t$. The parameter $\Delta S I_{k, t-j}^{D}$ is the lagged return on a specific developed stock market index: as a proxy for Europe we employ the German DAX index from the Frankfurt stock exchange and for the U.S.A. we employ the Dow Jones Industrial Average of 30 stocks index. Coefficient $\rho$ captures the effects of market spillovers from the two developed markets. The parameter $\Delta S I_{i, t-j}^{E}$ is the lagged return on a specific emerging market stock index other than that employed as a dependent variable and coefficient $\mu$ captures the effects of spillovers from the other two emerging markets (e.g., in the case of the Budapest index being the dependent variable, lagged indices from Prague and Warsaw are right-hand side variables). A vector of the pooled news defined in Section 2.1 is denoted as $x n_{k} . S x n_{k}$ is a vector of single news and $M x n_{k}$ is vector of multiple news. In all cases subscript $k$ indexes the origin of the announcements, either Europe (EU) or the U.S.A. (US). Further, subscript $j$ indexes the news entering our specification to reveal a different reaction to excess positive $(+)$, excess negative (-) or no-impact (0) news expected from a behavioral point of view. Coefficients $\chi, \gamma$ and $\delta$ capture the contemporaneous effects of pooled, single and multiple news, respectively, on stock index returns. The numbers of lags $p, q, r$, and $s$ are chosen by the lag selection information criteria. The $\log$ of the conditional variance in the mean equation, i.e., $\ln h_{t}$, allows for an exponential rather than quadratic effect of observed volatility.

In the above conditional variance specification, the $\mathrm{ARCH}$ term, $\alpha \varepsilon_{t-1}^{2}$, primarily reflects the impact of news or surprises from previous periods that affect stock price volatility. A significant and positive value of $\alpha$ that is less than one characterizes the extent to which shocks do not destabilize volatility. When $\alpha$ is greater than one, shocks from the past are destabilizing. The GARCH term $\beta h_{t-1}$ measures the impact of the forecast variance from previous periods on the current conditional variance or volatility. Hence, a significant value for $\beta$ that is close to one indicates a high degree of persistence in stock price volatility. The sum of both coefficients, i.e., $\alpha$ plus $\beta$, indicates the speed of convergence of the forecast of the conditional volatility to a steady state. The closer its value is to one, the slower the convergence.

Finally, as behavior on these markets has been documented to follow periods of lower and higher activity during a trading day, our analysis is performed by using periods of lower volatility during a standard trading period and separating periods of high volatility during the 
first 15 minutes after the opening, and the last 5 minutes before the closing, of the trading session. ${ }^{13}$ This approach avoids mixing periods of varying volatility during the trading day and reflects the $U$-shape pattern documented for volatility in various markets (McMillan and Speight, 2002; Fan and Lai, 2006), including the three emerging markets under research (Égert and Kočenda, 2007). ${ }^{14}$

Based on the Akaike information criterion and the Schwarz-Bayesian information criterion and the significance of the coefficients, we select a specific version of the baseline model that corresponds best to the data on each stock index. The standardized residuals from such a specification are free from ARCH effects. Estimation of the model uses a loglikelihood function, $\ln L_{t}=-0.5\left(\ln \left(2 \pi h_{t}\right)+\sum_{t=t_{0}}^{T} \varepsilon_{t}^{2} / h_{t}\right)$, as in Bollerslev (1986). The maximum-likelihood estimates are obtained by using the numerical optimization algorithm described by Berndt et al. (1974). To avoid the risk of overestimating volatility, we do not impose the normality condition on the distribution of errors. Rather, we allow for generalized error distribution (GED) following Nelson (1991). The volatility of stock prices is likely to follow a leptokurtic data distribution that is reflected by an actual GED parameter considerably lower than 2 , which is the value in the case of normal distribution. Leptokurtosis implies that daily stock price volatility tends to concentrate around the mean during tranquil market periods but that shocks to volatility are large during turbulent times.

The above specification accounts for the effect of various types of news on the firms' market value, hence the value of the market index. The emerging European stock markets are documented to be influenced by EU news but also by U.S. macroeconomic announcements at 14:30 CEDT and by the opening of the U.S. stock markets at 15:30 CEDT. The news from these two regions is hypothesized to exhibit the most direct influence on the new EU stock markets. The specification also accounts for the spillover effects through the lagged indices of neighboring emerging stock markets as well as lagged German and U.S. indices. Since trading hours in different markets span over different time periods we treat this difference by estimating the set of mean equations for each of the three emerging markets as seemingly unrelated regressions. This way we also allow for common features in the CEE markets to affect our estimates. Further, because of the time difference, there is a limited trading overlap between Europe and the U.S. Due to this short common window we estimate the U.S.

\footnotetext{
${ }^{13}$ These times were chosen based on a sensitivity analysis. Further adjustments did not change results.

${ }^{14}$ Such a pattern could be explained by the arrival and incorporation of news during the beginning of the trading day or by intraday trading activity, implying the opening and closing of positions at the beginning and at the end of the trading session.
} 
spillover effect in a separate regression. The coefficients of the volatility equation are estimated via maximum likelihood estimation.

\section{Empirical Findings}

To derive our empirical findings we first estimated the specification that includes the available local news. The estimation was performed with both pooled news announcements (specification 1.A) as well as single and multiple news (specification 1.B). We do not report those results for reasons given below, but the results are available upon request. In all three markets the overwhelming majority of the important news (e.g., GDP or inflation) is released before trading begins and therefore the markets have time to absorb the information prior to the trading session. This institutional arrangement means that the market opening already reflects the announcements to a large extent. Further, traders and market makers form expectations about the announcements in advance and these expectations are very accurate. ${ }^{15}$ Most of the news then comes as no surprise and since they are processed even before trading begins, their effect is dampened dramatically. In particular, local Czech announcements during the day usually do not reach the magnitude of those made public before the trading starts and this is evidenced by the insignificant coefficients. In Hungary, about $80 \%$ of the scheduled announcements are released before the trading on the market begins and we have found that the vast majority is in line with market expectations. The absence of any domestic news impact is then quite sensible. Also in Poland the local announcements do not play a role despite the fact that Warsaw records the smallest proportion of days when no news occurs during the trading window. Announcements of key importance are usually released before trading starts. Moreover, market opening in Warsaw is quite late, at 10 a.m., which makes any announcement almost irrelevant at market opening. The absence of local news of essential importance during the trading window is evidenced by the insignificant coefficients (not reported).

Thus, our main empirical findings come from a specification that includes foreign news. First, we estimated specification 1.A with pooled foreign news announcements. The results are presented in Tables 4-6 for each of the three countries separately. They show considerable spillover effects reaching the new EU markets and the presence of the news impact on the index returns in general. However, the impact differs with respect to the extent

\footnotetext{
${ }^{15}$ For example, central bank key interest rate announcements are released during the trading session but in an overwhelming majority of cases these announcements are fully in line with expectations on all three new EU markets.
} 
and origin of the news as well as the impacted stock market. The Prague market is negatively affected by negative U.S. news $\left(\chi_{3}\right)$ and the U.S. news that is in line with the market $\left(\chi_{5}\right)$. The Budapest market is negatively affected by negative U.S. news $\left(\chi_{3}\right)$ and positively affected by negative EU news $\left(\chi_{4}\right)$. The Warsaw market seems to be unaffected by foreign news.

Then, we estimated specification 1.B with foreign news divided between single and multiple announcements in order to find which group of news drives the results. The effects of multiple announcements are difficult to decompose and the question is whether we should see a stronger or weaker impact of multiple events as opposed to single news. We show that by splitting the announcements we can provide incremental information on the effect of news on stock prices. Therefore, we report detailed results in additional columns in the tables and comment on those results in the three following subsections 3.1-3.3. On the Prague market we see a stronger impact of multiple news $\left(\delta_{1}, \delta_{3}, \delta_{5}\right)$, that drives our results. On the Budapest market again multiple news $\left(\delta_{4}\right.$ and $\left.\delta_{6}\right)$ exhibits a stronger impact than single news $\left(\gamma_{3}\right)$. On the Warsaw market the decomposition is not possible due to insignificant coefficients.

\subsection{Czech Republic}

The returns on the Czech stock index PX-50 are affected by the developments of both Hungarian and Polish indices (Table 4). The effect of Warsaw $\left(\mu_{5}\right.$ and $\left.\mu_{6}\right)$ is about three to four times larger than that of Budapest $\left(\mu_{1}\right.$ and $\left.\mu_{2}\right)$ but both effects are small relative to the spillover from Frankfurt $\left(\rho_{1}\right.$ and $\left.\rho_{2}\right)$. Spillover from the U.S. $\left(\rho_{3}\right.$ and $\left.\rho_{4}\right)$ is limited as the window of the common trading with Prague is very short and within it the effect of the U.S. and German indices is mixed together. Separate estimates show that there is a positive immediate spillover effect from the U.S. whose magnitude is about one third of the German spillover $\left(\rho_{3}=0.005\right.$ when compared to $\left.\rho_{1}=0.014\right)$. Single announcements originating in the U.S. $\left(\gamma_{1}, \gamma_{3}, \gamma_{5}\right)$ do not affect the stock returns at all but multiple announcements $\left(\delta_{1}, \delta_{3}, \delta_{5}\right)$ do. Positive multiple U.S. announcements exhibit a positive effect $\left(\delta_{l}\right)$ while negative announcements and those that are in line with market expectations exhibit a negative effect $\left(\delta_{3}, \delta_{5}\right)$. The negative effect is about $50 \%$ stronger and this confirms multiple findings in the literature showing an asymmetric impact with negative news having a larger impact. News that is in line with the market has the strongest impact as if it is reflecting market disappointment with "no news". The impact of single positive EU news is negative $\left(\gamma_{2}\right)$ and it is the only significant effect found. The fact that the effect of positive news is negative is surprising. However, in the European marketplace a positive news release related to the territory of the old EU members might be interpreted by the market as a signal to transfer 
funds from the new EU market to get higher gains. This interpretation has to be backed by large amounts of funds transferred and has to be paired with the heavy presence of foreign investors who tend to put more weight on foreign news. The presence of foreign investors on the Czech market is heavy and varies around $55-60 \%$ of the traded volume over time. ${ }^{16}$ The path dependent behavior of the returns is confirmed by the significant coefficient of the conditional variance in the mean equation $(\theta)$. The impact of the lagged volatility should not be overestimated as its magnitude is much smaller than that of the combined effect of the news.

In our specification, the ARCH term $\alpha \varepsilon_{t-1}^{2}$ reflects the impact of news or surprises from previous periods that affect stock price volatility. We find a relatively small coefficient $\alpha$, meaning that news are well accounted for in the mean equation, past news do not affect volatility to a great extent, and they do not destabilize volatility. On the other hand, the $\beta$ coefficient in the GARCH term, $\beta h_{t-1}$, is quite large and indicates that no matter how large or small the effect of the news on volatility is, the impact of the forecast variance from previous periods on the current conditional variance, or volatility, is considerably persistent. Finally, the fact that the sum of both coefficients, i.e., $\alpha$ plus $\beta$, is close to one indicates that the convergence of the conditional volatility to a steady state is very slow.

\subsection{Hungary}

The Hungarian stock index exhibits considerable spillover effects from both neighboring markets, with the effect of the Prague market $\left(\mu_{3}\right.$ and $\left.\mu_{4}\right)$ three to four times stronger than that of Warsaw $\left(\mu_{5}\right.$ and $\left.\mu_{6}\right)$. The Warsaw effect is more stable in time, however (Table 5). The effect of the Frankfurt market $\left(\rho_{1}\right.$ and $\left.\rho_{2}\right)$ lies between the former two. Separate estimates show that there is no spillover effect from the U.S. $\left(\rho_{3}\right.$ and $\left.\rho_{4}\right)$. The Hungarian index is strongly and positively impacted by multiple negative announcements originating in the EU $\left(\delta_{4}\right)$ as well as those that are in line with market expectations $\left(\delta_{6}\right)$. In-line news is even stronger than multiple negative EU announcements, which means that the Budapest market reacts positively when expectations regarding EU news are below market expectations or are confirmed by actual releases. This is an interesting finding since Hungary has been having problems with inflation, fiscal discipline, deficit and other macroeconomic parameters for a considerable time. Below market and in-line with the market EU news may substitute for less

\footnotetext{
${ }^{16}$ We are grateful to the Prague Stock Exchange (PSE) for the results of the analysis on the structure of investors and information on the proportion of foreign investors on the Czech capital market. We are also indebted to the PSE for facilitating similar information from Budapest and Warsaw stock exchanges.
} 
than optimal domestic performance. Alternatively, the negative or neutral old EU news having a positive impact may be interpreted by the market as a signal to transfer funds to the new EU market to get higher gains, which is an inverse parallel to the Czech market. Again, this interpretation calls for large amounts of funds transferred by foreign investors being significantly present on the market and their sensitivity to foreign news. The presence of foreign investors on the Hungarian market is heavy (about $75 \%$ ) and dominated by investors from the old EU countries, according to the Budapest Stock Exchange. ${ }^{17}$ The Budapest market also reacts strongly to single negative U.S. news $\left(\gamma_{3}\right)$ and the effect is understandably negative.

The path dependence of the returns with respect to volatility is not confirmed as the volatility coefficient in the mean equation $(\theta)$ is insignificant. Further, past news $(\alpha)$ affect volatility to a moderate extent and they are not destabilizing. The volatility of the Hungarian stock index exhibits lower persistence (indicated by the value of the GARCH term $\beta h_{t-1}$ ) than the Czech one but more than the Polish index. Finally, the speed of the convergence of the forecast of the conditional variance to a steady state is very slow.

\subsection{Poland}

From Table 6 we see that the Polish stock index is moderately affected by spillovers from Prague $\left(\mu_{3}\right.$ and $\left.\mu_{4}\right)$ and only a little from Budapest $\left(\mu_{1}\right.$ and $\left.\mu_{2}\right)$. On the other hand, the effect of the Budapest market is more stable in time. The effect of the spillover from Frankfurt $\left(\rho_{l}\right.$ and $\rho_{2}$ ) is about same as that of Prague, both in terms of extent as well as decay in time. Separate estimates show that there is no spillover effect from the U.S. $\left(\rho_{3}\right.$ and $\left.\rho_{4}\right)$. From the perspective of news transmission, the Polish stock market represents the least affected market in the region under research. There is no effect of EU or U.S. news in any form since announcements are not found to leave a trace on the developments of the returns as none of the associated coefficients is significant. The single exception is a moderate negative effect of multiple announcements originating in the EU that are in line with market expectations $\left(\delta_{6}\right)$. This finding can be explained by the fact that the Polish stock market has the smallest participation of foreign investors among its regional counterparts; only about one third of the traded volume, as reported by the Warsaw Stock Exchange. We conjecture that for this reason foreign announcements do not have such a large impact as the foreign investors are a minority. The rest of the market is captured by local traders and pension funds. The domestic institutional investors are accustomed to maintaining relatively stable portfolios that exclude

\footnotetext{
${ }^{17}$ National Bank of Hungary reports even higher proportion of the value of traded stocks by foreign investors that ranges between $77-79 \%$ for the period under research.
} 
"overshooting" reactions to intraday news. An alternative explanation for the lack of significance of news announcements is that the information conveyed does not go beyond the information contained in foreign stock prices.

The path dependent behavior of the returns with respect to their own volatility is not present as the coefficient of the conditional variance in the mean equation $(\theta)$ is insignificant. In terms of volatility alone, we find that past news $(\alpha)$ affects volatility to the largest extent among all three markets, but it is not destabilizing. On other hand, the volatility of the Polish stock index exhibits the lowest persistence $(\beta)$ with respect to its regional counterparts. Similar to the Prague and Budapest index returns, the speed of the convergence of the forecast of the conditional variance to a steady state is very slow.

\subsection{Robustness Check}

We have reported the estimated results for each country based on the full set of available single and multiple foreign announcements. We also explored the question whether there are any types of announcements that are more important than others with respect to market reaction. To accomplish the task we selected several major types of announcements that are documented in the literature to exhibit a larger impact on stock markets. These are announcements on GDP, inflation and interest rate. We then re-estimated our specification with a sub-sample of higher impact announcements and compared the results with those obtained during days where no announcement occurred as a control sub-sample. ${ }^{18}$ Both sets of results were not materially different as no effect of the group of higher-impact announcements was found. Based on the results of our robustness estimations we conclude that our analysis truly captures the impact of specific news releases rather than a particular time-of-the-day pattern. The result of our robustness check is further corroborated by the fact that in our sample we have a large number of days when no announcements were released and this number is also quite high relative to the sum of the announcements during trading windows (see again Table 2).

\section{Concluding Remarks}

We estimate the impact of macroeconomic announcements on stock market returns and volatility in the three most liquid emerging European Union markets: the Czech Republic, Hungary, and Poland. Previous studies, mostly from developed markets, indicate that the

\footnotetext{
${ }^{18} \mathrm{We}$ are grateful to an anonymous referee for suggesting this extension. Detailed results are not reported but they are available upon request.
} 
impact of macroeconomic announcements on stock market activity is either small or insignificant. Employing intraday data and the excess impact approach, and primarily foreign news, we provide more comprehensive evidence and reliable inferences on the impact of news in emerging markets. Our evidence indicates that the importance of macroeconomic news on stock returns may be sensitive to the institutional structures of the markets studied, as well as the presence of foreign investors. While we find the impact of foreign news is not overwhelming, it more frequently has an impact in countries with a larger proportion of foreign investors. Further, since the number of announcements that are in line with market expectations is about five times smaller than the total number of news that come as a surprise, the in-line news do not explain the limited impact of the announcements. In addition, we show that the impact of multiple announcements is stronger than that of single news. One important lesson for future studies is that institutional factors should be considered more seriously and given more weight in interpreting the significance of foreign macroeconomic news in emerging financial markets, especially with heavy foreign trading.

We find that deviations from expectations play an important role in the EU emerging stock markets. The finding validates the use of our excess impact approach, yielding important insights into the arguments of Rigobon and Sack (2006) who claim that the "detachment" of monetary policy expectations and asset prices from incoming economic news is partly related to the difficulties associated with measuring the surprise component of that news. Using the excess impact approach, we attempt to reduce the difficulties of measuring "news" correctly.

Regarding the relative impact of U.S. versus EU foreign macroeconomic announcements on stock returns, news originating in the EU affects the returns in Prague, Budapest and Warsaw markets, while U.S. announcements have an impact on the Prague and Budapest markets only. The results for the Czech stock market do reflect the fact that a very significant part of the traded volume is due to foreign investors. These market players put more weight on foreign announcements which shows in the direct impact of U.S. news releases on the Prague stock index. This finding is consistent with previous studies that find a reduced role for macroeconomic news when composite indices are included in regressions. Local macroeconomic news does not have immediate (intraday) effects on returns in all markets as the majority of scheduled announcements are released before trading on the market begins. This, however, does not rule out that domestic news affect the markets between subsequent trading sessions. In general, emerging markets with stronger dependence on 
developed foreign stock markets react less to foreign macro announcements. This finding supports the notion that macro news can be transmitted by spillovers in asset prices.

In terms of volatility effects, stock returns show strong path-dependency on their own conditional variance (volatility) which is highly persistent in the Prague market but insignificant in the Budapest and Warsaw markets. This may reflect the higher degree of financial spillover effects to the Prague market originating from both the EU and U.S. markets directly through the composite index movements and indirectly via macroeconomic announcements. News affects volatility as the $\mathrm{ARCH}$ term in the conditional variance equation is statistically significant. News has a larger effect on volatility in the Budapest and Warsaw markets than the Prague market, indicating that the Prague market is calmer than the former markets. Perhaps this finding is due to more informed trading in the Czech market because of the large foreign investor presence.

Overall, we find that all three of these new EU stock markets are subject to significant spillovers directly via the composite index returns from the EU, the U.S. and neighboring markets among which Budapest exhibits the strongest spillover effect, followed by Warsaw and Prague. The Czech and Hungarian markets are also subject to spillovers indirectly through the transmission of macroeconomic news. The impact of EU-wide announcements is evidenced more in case of Hungary, while the Czech market is more impacted by U.S. news. The Polish market is marginally affected by EU news that is in line with expectations. We document that the impact of foreign macroeconomic announcements goes beyond the impact of the foreign stock markets on CEE indices.

The results have important implications for diversification and risk management strategies in these European emerging markets. As these countries prepare to enter the euro zone, we expect that their financial markets will be more sensitive to macroeconomic shocks, especially those originating from the European Union. This means that investors should price this expected higher future volatility (risk) when investing in these markets now. From a broader perspective, we find that the emerging markets in our sample countries seem to react similarly to macroeconomic news compared to those in advanced industrial markets. This finding suggests that the emerging European countries have made significant progress in terms of financial market development by successfully integrating their financial markets into the world economy in a relatively short period. Hence, the results provide incentives for the other emerging economies in the region to speed up economic reforms. This is also encouraging for lagging economies in the region, especially for the candidate EU countries. 


\section{References}

Albuquerque, R., Vega, C., 2006, Asymmetric Information in the Stock Market: Economic News and Co-movement. CEPR Discussion Paper 5598.

Berndt, E. K., Hall, B. H., Hall, R. E., Hausman, J.A., 1974, Estimation of inference in nonlinear structural models. Annals of Economic and Social Measurement 4, 653-665.

Bollerslev, T., 1986, Generalized autoregressive conditional heteroscedasticity. Journal of Econometrics 31, 307-327.

Bollerslev, A. T., Cai, J., 2000, Intraday and Interday Volatility in the Japanese Stock Market. Journal of International Financial Markets, Institutions, and Money 10, 107-130.

Bomfim, A. N., 2001, Pre-announcement effects, News Effects, and Volatility: Monetary Policy and the Stock Market, Journal of Banking and Finance 27, 133-151.

Bredin, D., Hyde, S., O’Reilly, G., 2005, European Monetary Policy Surprises: The Aggregate and Sectoral Stock Market, Economic Analysis and Research Department Working Paper 10/RT/2005, Central Bank and Financial Services Authority of Ireland.

Chun, R. M., 2000, Compensation vouchers and equity markets: Evidence from Hungary, Journal of Banking \& Finance 24 (7), 1155-1178.

Égert, B., Kočenda, E., 2007, Interdependence between Eastern and Western European Stock Markets: Evidence from Intraday Data. Economic Systems, 31(2), 184-203.

Ehrmann, M., Fratzscher, M., 2004, Taking Stock: Monetary Policy Transmission to Equity Markets, Journal of Money, Credit and Banking 36(4), 719-37.

Ehrmann, M., Fratzscher M., 2006, Global Financial Transmission of Monetary Policy Shocks, European Central Bank Working Paper No. 616.

Erenburg, G., Kurov A., Lasser D. J., 2005. Trading Around Macroeconomic Announcements: Are All Traders Created Equal?, Journal of Financial Intermediation 15, 470-493.

Fan, Y-J., Lai, H-N., 2006, The Intraday Effect and the Extension of Trading Hours for Taiwanese Securities. International Review of Financial Analysis 15, 328-347.

Fidrmuc, J., Korhonen, I., 2003. Similarity of Supply and Demand Shocks between the Euro Area and the CEECs, Economic Systems 27(3), 313-334.

Fidrmuc, J., Korhonen, I., 2006. Meta-Analysis of the Business Cycle Correlation between the Euro Area and the CEECs, Journal of Comparative Economics 34(3), 518-537.

Fink, G., Haiss, P. R., Orlowski L., Salvatore D., 1998, Central European Banks and Stock Exchanges: Capacity-building and Institutional Development, European Management Journal $16(4), 431-446$. 
Flannery, M. J., Protopapadakis A. A., 2002, Macroeconomic Factors Do Influence Aggregate Stock Returns, Review of Financial Studies 15, 751-782.

Gurkaynak, R., Sack, B., Swanson E. 2004, Do Actions Speak Louder than Words?: The Response of Asset Prices to Monetary Policy Actions and Statements, Finance and Economics Discussion Series 2004-66, Federal Reserve Board, Washington, D.C.

He, L. T., 2006, Variations in Effects of Monetary Policy on Stock Market Returns in the past Four Decades, Review of Financial Economics 15, 331-349.

Hermes, N., Lensink, R., 2000, Financial System Development in Transition Economies, Journal of Banking \& Finance 24 (4), 507-524.

Jensen, G. R., Johnson, R.R., 1995, Discount Rate Changes and Security Returns in the US, 1962-1991, Journal of Banking and Finance 19, 79-95.

Jensen, G. R., Mercer, J. M., Johnson, R. R., 1996, Business Conditions, Monetary Policy, and Expected Security Returns, Journal of Financial Economics 40, 213-237.

Jones, B., Chieng-Ting, L., Masih M. M., 2005, Macroeconomic Announcements, Volatility, and Interrelationships: An Examination of the UK Interest Rate and Equity Markets, International Review of Financial Analysis 14, 356-375.

Korczak, P, Bohl, M. T., 2005, Empirical Evidence on Cross-listed Stocks of Central and Eastern European Companies, Emerging Markets Review 6(2) 121-137.

Mamaysky, Harry, 2002, A Model For Pricing Stocks and Bonds. Yale ICF Working Paper No. 02-10.

Mann, T., Atra, R. J., Dowen, R., 2004, U.S. Monetary Policy Indicators and International Stock Returns, International Review of Financial Analysis 13, 543-558.

McMillan, D. G., Speight, A. E.H., 2002, Intra-day Periodicity and Long-Run Volatility, Econometrica 59, 347-370.

Nelson, D. B., 1991, Conditional heteroskedasticity in asset returns: A new approach. Macroeconomic News and Stock Valuation in Europe, Journal of Multinational Financial Management 14, 201-215.

Nikkinen, J., Omran, M., Sahlström, M., Äijö, A., 2006, Global stock market reactions to scheduled U.S. macroeconomic news announcements, Global Finance Journal 17 (1), 92-104.

Nikkinen, J., Sahlström, P., 2004, Scheduled domestic and U.S. macroeconomic news and stock valuation in Europe. Journal of Multinational Financial Management 14, 201-215.

Piazzesi, Monika, 2001, An Econometric Model of the Yield Curve with Macroeconomic Jump Effects. NBER Working Paper No. W8246.

Patelis, A. D., 1997, Stock Return Predictability and the Role of Monetary Policy, Journal of Finance 52(5), 1951-1972. 
Ramchander, S., Simpson, M. W., Thiewes H., 2006. The Effects of Macroeconomic News on German Closed-End Funds, Quarterly Review of Economics and Finance, In Press.

Rigobon, R., Sack, B., 2006, Noisy Macroeconomic Announcements, Monetary Policy, and Asset Prices, NBER Working Paper No. W12420.

Rockinger, M., Urga, G., 2000, The Evolution of Stock Markets in Transition Economies, Journal of Comparative Economics 28(3), 456-472.

Sangbae, K., In, F., 2002, The Influence of Foreign Stock Markets and Macroeconomic News Announcements on Australian Financial Markets, Pacific-Basin Finance Journal 10, 571-582.

Scholtens, B., 2000, Financial Regulation and Financial System Architecture in Central Europe, Journal of Banking \& Finance 24(4), 525-553.

Serwa, D., Bohl, M. T., 2005, Financial Contagion Vulnerability and Resistance: A Comparison of European Stock Markets, Economic Systems 29, 344-362.

Siklos, P. L., Anusiewicz, J., 1998, The Effect of Canadian and U.S. M1 Announcements on Canadian Financial Markets: The Crow Years, Journal of Economics and Business 50, 49-65.

Suk-Joong, K., McKenzie, M. D., Faff R. W. 2004, Macroeconomic News Announcements and the Role of Expectations: Evidence for US Bond, Stock and Foreign Exchange Markets, Journal of Multinational Financial Management 14, 217-232.

Tiago M., 2004, The risk and predictability of equity returns of the EU accession countries, Emerging Markets Review 5(2), 241-266.

Thorbecke, W., 1997, On Stock Market Returns and Monetary Policy, Journal of Finance 52, 635-654.

Tse, Y., Wu, C., Young, A., 2003, Asymmetric Information Transmission between a Transition Economy and the U.S. Market: Evidence from the Warsaw Stock Exchange, Global Finance Journal 14(3), 319-332.

Wongswan, J., 2006, Transmission of Information across International Equity Markets, Review of Financial Studies 19(4), 1157-1189.

Zalewska-Mitura, A., Hall, S. G., 1999, Examining the First Stages of Market Performance: A Test for Evolving Market Efficiency, Economics Letters 64(1), 1-12. 
Table 1

Descriptive statistics for main composite indices.

[Time span selected according to the trading hours of Prague, Budapest and Warsaw, i.e., 9:00 a.m. to 4:00 p.m.]

\begin{tabular}{lrrrrr}
\hline & $\begin{array}{l}\text { Number of } \\
\text { observations }\end{array}$ & Mean & Std. Dev. & Minimum & Maximum \\
\hline $\mathbf{2 0 0 3}$ & & & & & \\
\hline BUX & 13172 & 8861 & 670 & 7693 & 9975 \\
\hline PX50 & 11398 & 601 & 37 & 529 & 661 \\
\hline WIG20 & 10437 & 1464 & 136 & 1188 & 1739 \\
\hline $\mathbf{2 0 0 4}$ & & & & & \\
\hline BUX & 21745 & 11759 & 1434 & 9398 & 14806 \\
\hline PX50 & 18668 & 828 & 93 & 658 & 1034 \\
\hline WIG20 & 17174 & 1751 & 80 & 1577 & 1966 \\
\hline $\mathbf{2 0 0 5}$ & & & & & \\
\hline BUX & 22980 & 19018 & 2408 & 14560 & 23831 \\
\hline PX50 & 19699 & 1253 & 124 & 1032 & 1482 \\
\hline WIG20 & 18727 & 2174 & 250 & 1809 & 2702 \\
\hline $\mathbf{2 0 0 6}$ & & & & & \\
\hline BUX & 22253 & 22499 & 1279 & 18117 & 25513 \\
\hline PX50 & 18913 & 1480 & 90 & 1125 & 1632 \\
\hline WIG20 & 20437 & 2995 & 190 & 2453 & 3430 \\
\hline
\end{tabular}


Table 2. Daily distribution of news events (percent of all trading days)

\begin{tabular}{|l|c|c|c|c|c|}
\hline \hline & \multicolumn{5}{|c|}{ Days with types of news events: } \\
\cline { 2 - 6 } Country/Region & No news & $\begin{array}{c}\text { Single } \\
\text { news }\end{array}$ & $\begin{array}{c}\text { Multiple } \\
\text { news }\end{array}$ & $\begin{array}{c}\text { Single and } \\
\text { multiple } \\
\text { news }\end{array}$ & Total \\
\hline $\begin{array}{l}\text { European Union } \\
\text { United States }\end{array}$ & 70,18 & 22,44 & 6,25 & 1,13 & 100,00 \\
Czech Republic & 31,15 & 29,20 & 18,85 & 20,80 & 100,00 \\
Hungary & 91,39 & 8,61 & 0,00 & 0,00 & 100,00 \\
Poland & 95,70 & 4,30 & 0,00 & 0,00 & 100,00 \\
\hline \hline
\end{tabular}

Table 3. Daily distribution of news events that are released during trading window

\begin{tabular}{|c|c|c|c|c|}
\hline \multirow[t]{2}{*}{ Country/Region } & \multicolumn{4}{|c|}{$\begin{array}{l}\text { Classification and number of the news } \\
\text { events: }\end{array}$} \\
\hline & Positive & Negative & In-line & Total \\
\hline \multicolumn{5}{|l|}{ All news } \\
\hline European Union & 121 & 104 & 114 & 339 \\
\hline United States & 456 & 467 & 110 & 1033 \\
\hline Czech Republic & 24 & 31 & 29 & 84 \\
\hline Hungary & 8 & 5 & 29 & 42 \\
\hline Poland & 110 & 84 & 71 & 265 \\
\hline \multicolumn{5}{|l|}{ Single news } \\
\hline European Union & 99 & 86 & 82 & 267 \\
\hline United States & 295 & 285 & 32 & 612 \\
\hline Czech Republic & 24 & 31 & 29 & 84 \\
\hline Hungary & 8 & 5 & 29 & 42 \\
\hline Poland & 60 & 52 & 43 & 155 \\
\hline \multicolumn{5}{|l|}{ Multiple news } \\
\hline European Union & 22 & 18 & 32 & 72 \\
\hline United States & 161 & 182 & 78 & 421 \\
\hline Czech Republic & 0 & 0 & 0 & 0 \\
\hline Hungary & 0 & 0 & 0 & 0 \\
\hline Poland & 50 & 32 & 28 & 110 \\
\hline
\end{tabular}


Table 4. News and spillover effects: Prague Stock Exchange

\begin{tabular}{|c|c|c|c|c|c|c|}
\hline \multirow{2}{*}{ Parameter } & \multirow{2}{*}{\multicolumn{2}{|c|}{ Coefficient }} & \multicolumn{2}{|c|}{ Specification (1.A) } & \multicolumn{2}{|c|}{ Specification (1.B) } \\
\hline & & & Estimate & Std. error & Estimate & Std. error \\
\hline \multicolumn{7}{|c|}{ Stock index return } \\
\hline DAX $_{t-1}$ & & $\rho_{1}$ & $0,015^{* * *}$ & 0,002 & $0,014^{* * *}$ & 0,001 \\
\hline $\mathrm{DAX}_{\mathrm{t}-2}$ & & $\rho_{2}$ & 0,002 & 0,002 & $0,006^{* * *}$ & 0,001 \\
\hline DowJones $\mathrm{t}_{-}$ & & $\rho_{3}$ & $0,005^{* *}$ & 0,002 & $0,005^{* *}$ & 0,002 \\
\hline DowJones $t$ - & & $\rho_{4}$ & 0,000 & 0,001 & 0,000 & 0,001 \\
\hline BUX $_{t-1}$ & & $\mu_{1}$ & $0,002^{* * *}$ & 0,000 & $0,002^{* * *}$ & 0,000 \\
\hline BUX $_{t-2}$ & & $\mu_{2}$ & $0,001^{* *}$ & 0,000 & $0,001^{* * *}$ & 0,000 \\
\hline WIG20 $\mathrm{t}-1$ & & $\mu_{5}$ & $0,007^{* * *}$ & 0,002 & $0,005^{* * *}$ & 0,001 \\
\hline WIG20 t-2 & & $\mu_{6}$ & $0.003^{* *}$ & 0,001 & $0,006^{* * *}$ & 0,001 \\
\hline \multicolumn{7}{|c|}{ Pooled news announcement } \\
\hline Positive US & & $\chi_{1}$ & 0,011 & 0,038 & & \\
\hline Positive EU & & $\chi_{2}$ & 0,009 & 0,045 & & \\
\hline Negative US & & $\chi_{3}$ & $-0,060^{*}$ & 0,033 & & \\
\hline Negative EL & & $\chi_{4}$ & 0,090 & 0,128 & & \\
\hline In-line US n & & $\chi_{5}$ & $-0,150^{*}$ & 0,092 & & \\
\hline In-line EU $\mathrm{n}$ & & $\chi_{6}$ & $-0,032$ & 0,065 & & \\
\hline \multicolumn{7}{|c|}{ Single news announcement } \\
\hline Positive US & & $\gamma_{1}$ & & & $-0,013$ & 0,054 \\
\hline Positive EU & & $\gamma_{2}$ & & & $-0,154^{* *}$ & 0,068 \\
\hline Negative US & & $\gamma_{3}$ & & & $-0,035$ & 0,041 \\
\hline Negative EL & & $\gamma_{4}$ & & & 0,016 & 0,051 \\
\hline In-line US n & & $\gamma_{5}$ & & & 0,002 & 0,122 \\
\hline In-line EU n & & $\gamma_{6}$ & & & $-0,036$ & 0,047 \\
\hline \multicolumn{7}{|c|}{ Multiple news announcement } \\
\hline Positive US & & $\delta_{1}$ & & & $0,057^{*}$ & 0,034 \\
\hline Positive EU & & $\delta_{2}$ & & & 0,614 & 0,538 \\
\hline Negative US & & $\delta_{3}$ & & & $-0,079^{*}$ & 0,041 \\
\hline Negative EL & & $\delta_{4}$ & & & 0,800 & 0,513 \\
\hline In-line US n & & $\delta_{5}$ & & & $-0,334^{*}$ & 0,178 \\
\hline In-line EU n & & $\delta_{6}$ & & & 0,049 & 0,110 \\
\hline \multicolumn{7}{|c|}{ Path dependency } \\
\hline Conditional & ance & $\theta$ & $0,023^{* * *}$ & 0,008 & $0,023^{* * *}$ & 0,006 \\
\hline \multicolumn{7}{|c|}{ Volatility equation parameters } \\
\hline Constant & & $\omega$ & 0,000 & 0,000 & 0,001 & 0,000 \\
\hline $\mathrm{ARCH}$ term & & $\alpha$ & $0,022^{* * *}$ & 0,008 & $0,029^{* *}$ & 0,010 \\
\hline GARCH ter & & $\beta$ & $0,977^{* * *}$ & 0,008 & $0,971^{* * *}$ & 0,010 \\
\hline \multicolumn{3}{|c|}{$\begin{array}{l}\text { Number of observations: } \\
61,680\end{array}$} & \multicolumn{2}{|c|}{$\begin{array}{l}\text { DW: } 1,71 \\
\text { SIC: } 50962 \\
\text { Log Likelihood: }-50875 \\
\text { Adjusted } \mathrm{R}^{2}: 0,018\end{array}$} & \multicolumn{2}{|c|}{$\begin{array}{l}\text { DW: } 1,79 \\
\text { SIC: } 55598 \\
\text { Log Likelihood: }-55477 \\
\text { Adjusted } R^{2}: 0,023\end{array}$} \\
\hline
\end{tabular}

Notes: $* * *, * *, *$ denote significant at $1 \%, 5 \%, 10 \%$ statistical test level, respectively. DW indicates the Durbin-Watson statistics and SIC stands for Schwarz-Bayesian information criteria. 
Table 5. News and spillover effects: Budapest Stock Exchange

\begin{tabular}{|c|c|c|c|c|c|}
\hline \multirow{2}{*}{ Parameter } & \multirow{2}{*}{ Coefficient } & \multicolumn{2}{|c|}{ Specification (1.A) } & \multicolumn{2}{|c|}{ Specification (1.B) } \\
\hline & & Estimate & Std. error & Estimate & Std. error \\
\hline \multicolumn{6}{|l|}{ Stock index return } \\
\hline $\mathrm{DAX}_{\mathrm{t}-1}$ & $\rho_{1}$ & $0,165^{* * *}$ & 0,018 & $0,161^{* * *}$ & 0,017 \\
\hline $\mathrm{DAX}_{\mathrm{t}-2}$ & $\rho_{2}$ & $0,113^{* * *}$ & 0,019 & $0,108^{* * *}$ & 0,018 \\
\hline DowJones $_{t-1}$ & $\rho_{3}$ & $-0,026$ & 0,039 & $-0,026$ & 0,039 \\
\hline DowJones $t_{-2}$ & $\rho_{4}$ & $-0,009$ & 0,022 & $-0,009$ & 0,022 \\
\hline PX50 t-1 & $\mu_{3}$ & $0,448^{* * *}$ & 0,128 & $0,454^{* * *}$ & 0,118 \\
\hline PX50 t-2 & $\mu_{4}$ & $0,314^{* *}$ & 0,126 & $0,266^{* *}$ & 0,117 \\
\hline WIG20 $\mathrm{t}-1$ & $\mu_{5}$ & $0,103^{* * *}$ & 0,025 & $0,105^{* * *}$ & 0,024 \\
\hline $\mathrm{WIG} 20_{\mathrm{t}-2}$ & $\mu_{6}$ & $0,101^{* * *}$ & 0,025 & $0,095^{* * *}$ & 0,024 \\
\hline \multicolumn{6}{|c|}{ Pooled news announcement } \\
\hline Positive US news & $\chi_{1}$ & $-0,133$ & 0,642 & & \\
\hline Positive EU news & $\chi_{2}$ & 0,126 & 0,849 & & \\
\hline Negative US news & $\chi_{3}$ & $-1,120^{*}$ & 0,598 & & \\
\hline Negative EU news & $\chi_{4}$ & $10,778^{* * *}$ & 3,908 & & \\
\hline In-line US news & $\chi_{5}$ & 0,274 & 1,387 & & \\
\hline In-line EU news & $\chi_{6}$ & 1,167 & 1,428 & & \\
\hline \multicolumn{6}{|c|}{ Single news announcement } \\
\hline Positive US news & $\gamma_{1}$ & & & $-0,235$ & 0,772 \\
\hline Positive EU news & $\gamma_{2}$ & & & 1,660 & 1,228 \\
\hline Negative US news & $\gamma_{3}$ & & & $-1,517^{*}$ & 0,867 \\
\hline Negative EU news & $\gamma_{4}$ & & & $-0,830$ & 1,163 \\
\hline In-line US news & $\gamma_{5}$ & & & 0,894 & 1,834 \\
\hline In-line EU news & $\gamma_{6}$ & & & 1,318 & 1,143 \\
\hline \multicolumn{6}{|c|}{ Multiple news announcement } \\
\hline Positive US news & $\delta_{1}$ & & & $-0,466$ & 0,784 \\
\hline Positive EU news & $\delta_{2}$ & & & $-2,698$ & 9,658 \\
\hline Negative US news & $\delta_{3}$ & & & $-0,765$ & 0,774 \\
\hline Negative EU news & $\delta_{4}$ & & & $4,408^{*}$ & 2,579 \\
\hline In-line US news & $\delta_{5}$ & & & 0,147 & 1,678 \\
\hline In-line EU news & $\delta_{6}$ & & & $7,232^{*}$ & 3,817 \\
\hline \multicolumn{6}{|l|}{ Path dependency } \\
\hline Conditional variance & $\theta$ & 0,001 & 0,004 & 0,004 & 0,004 \\
\hline \multicolumn{6}{|c|}{ Volatility equation parameters } \\
\hline Constant & $\omega$ & $0,012^{* * *}$ & 0,002 & $0,012^{* * *}$ & 0,002 \\
\hline $\mathrm{ARCH}$ term & $\alpha$ & $0,089^{* * *}$ & 0,009 & $0,090^{* * *}$ & 0,008 \\
\hline GARCH term & $\beta$ & $0,909^{* * *}$ & 0,009 & $0,909^{* * *}$ & 0,008 \\
\hline \multicolumn{2}{|c|}{$\begin{array}{l}\text { Number of observations: } \\
61,680\end{array}$} & \multicolumn{2}{|c|}{$\begin{array}{l}\text { DW: } 1,76 \\
\text { SIC: } 215764 \\
\text { Log Likelihood: }-215677 \\
\text { Adjusted } \mathrm{R}^{2}: 0,007\end{array}$} & \multicolumn{2}{|c|}{$\begin{array}{l}\text { DW: } 1,71 \\
\text { SIC: } 245740 \\
\text { Log Likelihood: -245618 } \\
\text { Adjusted } \mathrm{R}^{2}: 0,013\end{array}$} \\
\hline
\end{tabular}

Notes: $* * *, * *, *$ denote significant at $1 \%, 5 \%, 10 \%$ statistical test level, respectively. DW indicates the Durbin-Watson statistics and SIC stands for Schwarz-Bayesian information criteria. 
Table 6. News and spillover effects: Warsaw Stock Exchange

\begin{tabular}{|c|c|c|c|c|c|c|}
\hline \multirow{2}{*}{ Parameter } & \multirow{2}{*}{\multicolumn{2}{|c|}{ Coefficient }} & \multicolumn{2}{|c|}{ Specification (1.A) } & \multicolumn{2}{|c|}{ Specification (1.B) } \\
\hline & & & Estimate & Std. error & Estimate & Std. error \\
\hline \multicolumn{7}{|c|}{ Stock index return } \\
\hline $\mathrm{DAX}_{\mathrm{t}-1}$ & & $\rho_{1}$ & $0,071^{* * *}$ & 0,005 & $0,069^{* * *}$ & 0,004 \\
\hline $\mathrm{DAX}_{\mathrm{t}-2}$ & & $\rho_{2}$ & $0,022^{* * *}$ & 0,004 & $0,021^{* * *}$ & 0,004 \\
\hline DowJones $\mathrm{t}_{-}$ & & $\rho_{3}$ & 0,010 & 0,008 & 0,010 & 0,008 \\
\hline DowJones $\mathrm{t}$ - & & $\rho_{4}$ & $-0,003$ & 0,004 & $-0,003$ & 0,004 \\
\hline BUX $_{t-1}$ & & $\mu_{1}$ & $0,005^{* * *}$ & 0,001 & $0,005^{* * *}$ & 0,001 \\
\hline BUX $_{t-2}$ & & $\mu_{2}$ & $0,004^{* * *}$ & 0,001 & $0,004^{* * *}$ & 0,001 \\
\hline PX50 t-1 & & $\mu_{3}$ & $0,052^{* * *}$ & 0,017 & $0,056^{* * *}$ & 0,016 \\
\hline PX50 t-2 & & $\mu_{4}$ & $0,030^{*}$ & 0,017 & $0,027^{*}$ & 0,016 \\
\hline \multicolumn{7}{|c|}{ Pooled news announcement } \\
\hline Positive US & & $\chi_{1}$ & $-0,163$ & 0,230 & & \\
\hline Positive EU & & $\chi_{2}$ & 0,112 & 0,171 & & \\
\hline Negative US & & $\chi_{3}$ & 0,114 & 0,243 & & \\
\hline Negative EL & & $\chi_{4}$ & $-0,665$ & 0,448 & & \\
\hline In-line US n & & $\chi_{5}$ & $-0,029$ & 0,177 & & \\
\hline In-line EU n & & $\chi_{6}$ & $-0,228$ & 0,234 & & \\
\hline \multicolumn{7}{|c|}{ Single news announcement } \\
\hline Positive US & & $\gamma_{1}$ & & & 0,000 & 0,269 \\
\hline Positive EU & & $\gamma_{2}$ & & & 0,035 & 0,237 \\
\hline Negative US & & $\gamma_{3}$ & & & 0,101 & 0,267 \\
\hline Negative EL & & $\gamma_{4}$ & & & 0,103 & 0,185 \\
\hline In-line US n & & $\gamma_{5}$ & & & 0,160 & 0,542 \\
\hline In-line EU n & & $\gamma_{6}$ & & & $-0,135$ & 0,170 \\
\hline \multicolumn{7}{|c|}{ Multiple news announcement } \\
\hline Positive US & & $\delta_{1}$ & & & $-0,140$ & 0,242 \\
\hline Positive EU & & $\delta_{2}$ & & & 0,936 & 2,244 \\
\hline Negative US & & $\delta_{3}$ & & & 0,107 & 0,307 \\
\hline Negative EL & & $\delta_{4}$ & & & 0,688 & 1,037 \\
\hline In-line US n & & $\delta_{5}$ & & & $-0,160$ & 0,230 \\
\hline In-line EU n & & $\delta_{6}$ & & & $-0,604^{*}$ & 0,376 \\
\hline \multicolumn{7}{|c|}{ Path dependency } \\
\hline Conditional & ance & $\theta$ & 0,003 & 0,004 & 0,005 & 0,004 \\
\hline \multicolumn{7}{|c|}{ Volatility equation parameters } \\
\hline Constant & & $\omega$ & $0,160^{* * *}$ & 0,018 & $0,154^{* * *}$ & 0,017 \\
\hline $\mathrm{ARCH}$ term & & $\alpha$ & $0,125^{* * *}$ & 0,008 & $0,123^{* * *}$ & 0,007 \\
\hline GARCH ter & & $\beta$ & $0,859^{* * *}$ & 0,009 & $0,861^{* * *}$ & 0,008 \\
\hline \multicolumn{3}{|c|}{$\begin{array}{l}\text { Number of observations: } \\
61,680\end{array}$} & \multicolumn{2}{|c|}{$\begin{array}{l}\text { DW: } 1,79 \\
\text { SIC: } 55598 \\
\text { Log Likelihood: }-55477 \\
\text { Adjusted } R^{2}: 0,016\end{array}$} & \multicolumn{2}{|c|}{$\begin{array}{l}\text { DW: } 1,86 \\
\text { SIC: } 140351 \\
\text { Log Likelihood: }-140230 \\
\text { Adjusted } \mathrm{R}^{2}: 0,020\end{array}$} \\
\hline
\end{tabular}

Notes: $* * *, * *, *$ denote significant at $1 \%, 5 \%, 10 \%$ statistical test level, respectively. DW indicates the Durbin-Watson statistics and SIC stands for Schwarz-Bayesian information criteria. 
Appendix: Table A.1

Composition of the stock market indices in Prague, Budapest and Warsaw

\begin{tabular}{|c|c|c|}
\hline Stock Issuer & Stock Weight & Issuer Domicile \\
\hline \multicolumn{3}{|c|}{ Budapest Stock Exchange Index (BUX) } \\
\hline DANUBIUS & $0.9 \%$ & $\mathrm{D}$ \\
\hline ECONET & $0.1 \%$ & $\mathrm{D}$ \\
\hline EGIS & $2.0 \%$ & $\mathrm{D}$ \\
\hline ÉMÁSZ & $0.4 \%$ & $\mathrm{D}$ \\
\hline FHB & $1.2 \%$ & $\mathrm{D}$ \\
\hline FOTEX & $1.1 \%$ & $\mathrm{D}$ \\
\hline MAGYAR TELEKOM & $13.1 \%$ & $\mathrm{D}$ \\
\hline MOL & $32.9 \%$ & $\mathrm{D}$ \\
\hline OTP & $31.9 \%$ & $\mathrm{D}$ \\
\hline PANNONPLAST & $0.7 \%$ & $\mathrm{D}$ \\
\hline RÁBA & $0.7 \%$ & $\mathrm{D}$ \\
\hline RICHTER & $14.4 \%$ & $\mathrm{D}$ \\
\hline SYNERGON & $0.3 \%$ & $\mathrm{D}$ \\
\hline TVK & $0.3 \%$ & $\mathrm{D}$ \\
\hline \multicolumn{3}{|c|}{ Prague Stock Exchange Index(PX-50) } \\
\hline ČEZ & $26.7 \%$ & $\mathrm{D}$ \\
\hline ERSTE BANK & $23.5 \%$ & $\mathrm{~F}$ \\
\hline TELEFÓNICAA O2 C.R. & $15.8 \%$ & $\mathrm{D}$ \\
\hline KOMERČNÍ BANKA & $14.5 \%$ & $\mathrm{D}$ \\
\hline CETV & $5.6 \%$ & $\mathrm{~F}$ \\
\hline UNIPETROL & $4.8 \%$ & $\mathrm{D}$ \\
\hline ZENTIVA & $4.1 \%$ & $\mathrm{~F}$ \\
\hline ORCO & $2.3 \%$ & $\mathrm{~F}$ \\
\hline PHILIP MORRIS ČR & $1.7 \%$ & $\mathrm{D}$ \\
\hline PEGAS NONWOVENS & $0.6 \%$ & $\mathrm{~F}$ \\
\hline ECM & $0.5 \%$ & $\mathrm{~F}$ \\
\hline \multicolumn{3}{|c|}{ Warsaw Stock Exchange Index (WIG-20) } \\
\hline PKOBP & $15.7 \%$ & $\mathrm{D}$ \\
\hline PEKAO & $13.1 \%$ & $\mathrm{D}$ \\
\hline PKNORLEN & $12.7 \%$ & $\mathrm{D}$ \\
\hline TPSA & $10.3 \%$ & $\mathrm{D}$ \\
\hline KGHM & $9.8 \%$ & $\mathrm{D}$ \\
\hline BANKBPH & $4.9 \%$ & $\mathrm{D}$ \\
\hline GTC & $4.1 \%$ & D \\
\hline BZWBK & $4.0 \%$ & $\mathrm{D}$ \\
\hline BRE & $3.4 \%$ & $\mathrm{D}$ \\
\hline PGNIG & $3.3 \%$ & $\mathrm{D}$ \\
\hline POLIMEXMS & $3.1 \%$ & $\mathrm{D}$ \\
\hline PBG & $2.4 \%$ & $\mathrm{D}$ \\
\hline TVN & $2.3 \%$ & $\mathrm{D}$ \\
\hline CERSANIT & $2.0 \%$ & $\mathrm{D}$ \\
\hline CEZ & $1.9 \%$ & $\mathrm{~F}$ \\
\hline MOL & $1.8 \%$ & $\mathrm{~F}$ \\
\hline LOTOS & $1.6 \%$ & $\mathrm{D}$ \\
\hline AGORA & $1.6 \%$ & $\mathrm{D}$ \\
\hline BIOTON & $1.1 \%$ & $\mathrm{D}$ \\
\hline PROKOM & $1.1 \%$ & $\mathrm{D}$ \\
\hline
\end{tabular}

Note: Issuer domicile can be domestic (D) or foreign (F). 
Individual researchers, as well as the on-line and printed versions of the CERGE-EI Working Papers (including their dissemination) were supported from the following institutional grants:

- Economic Aspects of EU and EMU Entry [Ekonomické aspekty vstupu do Evropské unie a Evropské měnové unie], No. AVOZ70850503, (2005-2010);

- Economic Impact of European Integration on the Czech Republic [Ekonomické dopady evropské integrace na ČR], No. MSM0021620846, (2005-2011);

Specific research support and/or other grants the researchers/publications benefited from are acknowledged at the beginning of the Paper.

(c) Jan Hanousek, Evžen Kočenda, Ali M. Kutan, 2007.

All rights reserved. No part of this publication may be reproduced, stored in a retrieval system or transmitted in any form or by any means, electronic, mechanical or photocopying, recording, or otherwise without the prior permission of the publisher.

Published by

Charles University in Prague, Center for Economic Research and Graduate Education (CERGE) and

Economics Institute ASCR, v. v. i. (EI)

CERGE-El, Politických vězňŭ 7, 11121 Prague 1, tel.: +420 224005 153, Czech Republic.

Printed by CERGE-EI, Prague

Subscription: CERGE-EI homepage: http://www.cerge-ei.cz

Editors: Directors of CERGE and EI

Managing editors: Deputy Directors for Research of CERGE and EI

ISSN 1211-3298

ISBN 978-80-7343-149-5 (Univerzita Karlova. Centrum pro ekonomický výzkum

a doktorské studium)

ISBN 978-80-7344-138-8 (Národohospodářský ústav AV ČR, v. v. i.) 
CERGE-EI

P.O.BOX 882

Politických vězňů 7

11121 Praha 1

Czech Republic http://www.cerge-ei.cz 